\title{
The Millennium Development Goals (MDGs) and the Challenges of Youth Development in Nigeria
}

\author{
Chukwuma Chinedu Ukachukwu' ${ }^{1} \&$ E. B. J. Iheriohanma ${ }^{2}$ \\ ${ }^{1}$ Department of Sociology, Faculty of Social Sciences, Imo State University, Owerri, Nigeria \\ ${ }^{2}$ Federal University of Technology, Owerri, Imo State, Nigeria \\ Correspondence: E. B. J. Iheriohanma, Federal University of Technology, P. M. B. 1526, Owerri, Imo State, \\ Nigeria. E-mail: iherioha2005@yahoo.com
}

Received: July 2, 2013 Accepted: August 15, 2013 Online Published: October 29, 2013

doi:10.5539/ass.v9n15p253

URL: http://dx.doi.org/ass.v9n15p253

\begin{abstract}
Despite the adoption of the Millennium Development Goals (MDGs) in 2000, the Nigerian youth is still caught in a web of poverty, hopelessness and missed opportunities. The paper argues that though corruption, lack of political will, poor policy implementation, etc. limit government's efforts at youth development, the primary challenge remains the fact that the government has not been able to properly conceptualise and prioritize youth development. In addition, government's implementation of the Millennium Development Goals remains manifestly insincere to an alarming degree. This paper relied on secondary information and data sourced from newspapers, magazines, journals, textbooks, etc. The methodology is analytical. The structural functionalist theory is adopted in the analysis. This study emphasizes the fact that the future progress of the Nigerian nation is critically tied to the quality of youths she is able to produce in the present. It posits that until government's efforts in the implementation of the MDGs become manifestly sincere to an appreciable degree and youth development is properly conceptuali(z)ed, the Nigerian youth will continue to be plagued by the challenges of poor value orientation(s delete s), disenchantment, negativity and inadequacy. The paper recommends that youth development should be given a priority attention in the ongoing constitutional review efforts in Nigeria.
\end{abstract}

Keywords: millennium development goals (MDGs), youth, Nigeria, youth development

\section{Introducing the Problem}

The concept of youth development has increasingly occupied the attention of scholars, youth activists, politicians and international organizations. This interest has increased in the new millennium because of the overwhelming awareness that "youths represent the most tangible investment that any country can have" (Osisioma, 2007). Osisioma's assertion that "the strength of our armies, the virility of our workforce, the resilience of our national values, the skill and dexterity of the professional class, all depend on the quality of our youth" further brings to the forefront the critical position which youths occupy in every society both now and in the future. They are, in a word, the 'future'. This is because the continued propagation of the successes or failures of every generation rests on the youth. It is the youth who will, in the future, become doctors, lawyers, engineers, politicians, teachers, businessmen, artisans, etc. who will manage the affairs of their society and who will also one day pass the baton of continuity over to the next generation of youths. It is therefore due to the primacy of the youth in every society that the concept of youth development was developed and also revolves around.

Ubi (2007, p.2) opines that "the youth phase of life is an interesting and an important phase of the development of any human society. This phase of life shows signs that an era (childhood) is over and marks the beginning of a new phase that transcends into adulthood". It is also described as "the period in an individual's life that runs between the end of childhood and entry into the world of work" (Onuekwusi \& Effiong, 2002). According to Nigeria's Youth Development Policy (2001), "the youth comprises all young persons of ages 18-35, who are citizens of the Federal Republic of Nigeria". They are seen as "the vital sources of manpower for development" (Olujide, 2008). Youths are usually referred to as the leaders of tomorrow. This is because it is the youth that usually receive the baton of nation building from the preceding adult population.

Chine (2003, p.9) opines that "youths are generally and rightfully referred to as the leaders of tomorrow". He continued that "consequently, every sane society with responsible and selfless leadership has constitutional 
arrangements whereby young ones are guided to imbibe the moral, social, economic and political value orientations" of that society. The purpose of these arrangements is hinged on the belief that the youths are imbued with potentials which when properly harnessed can be turned into assets to the benefit of the wider society. This becomes crucial in the light of the fact that when such potentials are improperly harnessed, the end result is usually destructive, thereby diminishing their value as the trustees of the society and the vital sources of manpower for societal development and continuity. Furthermore, this process of development usually involves not just the biological parents but all the people around the youth. These others are the wider family, the community and significantly, the government.

Nigeria is reputed to be the most populous country in Africa and the seventh most populated country in the world (Wikipedia, 2012; Ploch, 2013). By inference, a large part of this population is made up of youths. Since youths represent the most tangible investment that any nation can have, as well as its most vital source of manpower for present and future development, it is expected that the youths in Nigeria would be cherished, motivated and provided with all available skills, tools and enabling environment to ensure the full development and attainment of their potentials and promises. In other words, youth development should be doggedly pursued in Nigeria. The essence of this development is for youths to acquire and improve on such skills that are necessary for them to be able to protect and provide for themselves and their society in the future, especially in this worldwide web of economic integration.

The need for youth development becomes even more urgent when one considers the fact that Nigeria is presently immersed in a protracted and unprecedented crisis of under-development. As a consequence of this under-development, the Nigerian nation is regarded as a periphery or Third World country, a euphemism used to qualify the attributes of acute poverty, endemic internal conflicts, relatively high HIV/AIDS scourge, high unemployment, bad governance, electoral fraud and violence, manifest institutional inefficiency and void political and social cultures (Iheriohanma, 2009). One of the major outcomes has been increasing youth disenchantment, along with other attendant challenges for the youth. This has created a disjointed and false value orientation base, as well as a limited space to realise self for the Nigerian youth.

With the above in mind, the Millennium Development Goals (MDGs), a United Nations initiative, was introduced in the year 2000 to counter the trend and create an enabling environment in which youth and national development are properly facilitated and achieved (Nigerian Millennium Development Goals Report, 2010; Okoroafor \& Anuforo, 2012). Through the Millennium Development Goals (MDGs), national governments were encouraged to initiate and facilitate development programmes that will transform their societies and encourage the youths become veritable instruments of nation building in all signatory countries. Having set the year 2015 as the target date, the signatory nations aimed albeit, through the Millennium Development Goals (MDGs) to encourage and achieve social and economic development especially in the developing nations of the polar South among which Nigeria is included. Several years after, Nigeria still flounders in its attempt to achieve the objectives of the Millennium Development Goals and adequately address the problems and aspiration of the Nigerian youth (Bamidele et al., 2013; African Forum and Network on Debt and Development (AFRODAD), 2005). In addition to poor value orientation, the Nigerian youth continues to be plagued by the challenges of high rate of youth unemployment, youth neglect, social vices, poverty, negativism, inadequacy and ultimately, deviance and crime (Chukwuemeka et al., 2012). This paper aims to investigate the extent to which Nigeria has been able to achieve the lofty objectives of the Millennium Development Goals (MDGs) and the extent to which it has improved the development of its teeming and talented youth.

\section{The Challenging Problem of Youth Development and the MDGs}

Fifty-three years after independence, the Nigerian nation has not been able to adequately harness and develop the vast potentials possessed by its youth. The youths' desire for qualitative education, good health, challenging but fulfilling employment and general wellbeing appears to be mortgaged. Various youth development efforts or programmes have not translated into concrete tools by which the challenges faced by youths are ameliorated. The Hobbesian realities of the Nigerian socio-economic and political environment have reduced the youth's access to opportunities for economic growth which has continuously served to increase the excruciating vacuum in the youths' stomach and minds (Okafor, 2011; Chukuezi, 2009; Olasunkanmi, 2009; Yusif, 2008). Added to the above, it appears the Millennium Development Goals (MDGs) which were adopted in the year 2000 in Nigeria, has not been translated to verifiable implementation twelve years after their adoption and the advantages that would uplift youth development seem difficult to harness.

One cannot fail to notice that in the various societies which make up the Nigerian nation, the youths find themselves subjected to severe disadvantages. These disadvantages include illiteracy, inadequacy of skills, 
varying degrees of unemployment and under-employment, embarrassing dependence on extended family and friends, health related problems, poor access to start-off capital, etc. (Ubi, 2007). There is also exposure to corrupt influences which usually lead them to participate in violent crimes and thuggery (Iheriohanma, 2009). The Nigerian youths appear inhibited and incapable of fixing appropriately and approximately in this competitive and knowledge-driven global economy. Hence, the societal and national advantages that manifest from concise and effective development of youths appear elusive in the Nigerian environment.

The following questions become critical at this point. They include:

1) What were the dynamics of youth development in Nigeria before the introduction of the Millennium Development Goals (MDGs)?

2) What are the Millennium Development Goals (MDGs) and how would they benefit youths in Nigeria?

3) What has been the impact of the Millennium Development Goals (MDGs) on youth development in Nigeria?

Specifically, this study has the following as its objectives:

a) To examine the dynamics of youth development in Nigeria before the introduction of the Millennium Development Goals in Nigeria.

b) To analyze the Millennium Development Goals (MDGs) and highlight their advantages for youth development in Nigeria

c) To assess the impact of the Millennium Development Goals (MDGs) on youth development in Nigeria.

This study emphasizes the fact that the future progress of the Nigerian nation is critically tied to the quality of youths she is able to produce in the present. Youth development will lead to effective and long-lasting advantages for the youth. It fundamentally reminds policy makers of the need to walk the talk in policy formulation, implementation and actualization. Its recommendations will enable the government and other stakeholders to constructively tap into the advantages and opportunities as are inherent in the Millennium Development Goals (MDGs) bearing in mind that the Nigerian youth remain the only effective tool for national rebirth and transformation. The focus of the present administration of President Goodluck Jonathan can only be of critical benefit to Nigeria and Nigerians in the future if there are critical agenda for youth development in the present government's transformation agenda, taking into consideration the opportunities offered by the implementation of the MDGs.

Secondly, Information and Communications Technology (ICT) has redirected skills and knowledge development with regard to the world of work, economic and national development. World economy and development are now knowledge-driven and any human capital development must cue in line with the tenets. This is excruciatingly necessary now that the factors of globalization have affected manpower development globally.

This paper relied on secondary information and data sourced from newspapers, magazines, journals, textbooks, etc. The methodology is analytical.

\section{Theoretical Exposition}

To understand fully the increase in emphasis on the concept of youth development demands an in-depth review of the structural functionalist theory. This primarily, is because structural functionalism, as a sociological theory, sees the society as supported by the functions of each of the parts to the survival of the whole. It focuses on the society and the inter-relationships of the parts. The parts refer to the social institutions in the society. It concentrates on the structures of the society and their relationship to each other. The structural functionalists assume these structures to be mutually supportive and tending towards a dynamic equilibrium. The emphasis is on how order is maintained among the various elements of the society and change is seen as an orderly process.

Iheriohanma (1999, p.22) asserts that "functionalists regard the society as a system. Functionalists liken the society to a biological organism which has different parts ... each performing different but related functions to ensure the survival of the whole system". Social institutions like the family, education, economy, polity and religion have functions they perform in the society. While some may perform manifest functions, others perform latent functions. The aim is to attain homeostasis or equilibrium in the society. Unfortunately, it is not all segments of the society that adequately contribute to its survival or stability at all times. This creates tension and strain which usually lead to dysfunctionality. Dysfunctionality refers to an element or a process of society that may disrupt a social system or result to instability.

The youths in Nigeria, like their counterparts in other clime, aspire to have fulfilling experiences in life. They desire the assistance of the government and the society in developing themselves and in return, make 
contributions to the development of their society. Sadly, the social institutions found in Nigeria which form the fundamental basis of the society and from which the societal requirements are set have defaulted in their responsibilities. The major structural entities that should address the basic needs of the Nigerian society are weakened by weak norms and sanctions. Largely dysfunctional, the society finds it hard to integrate the social institutions such that the youths will be able to attain the basic goals and aspirations set for them by the society and which they also set for themselves in life. In this situation, institutional frameworks become perverted and policy formulation, implementation and actualization are appropriated purely for parochial interests.

This created an environment in which the youths' abilities and skills are undeveloped or under-developed. As the society is unable to fulfil its functional responsibility to the youths, it creates a vacuum of structural strain which is consequently filled by youth deviance and other forms of irrational youth action and which culminates in further under-development for the Nigerian youth (Iheriohanma, 2009).

\section{The Dynamics of Youth Development in Nigeria}

Former Nigerian president, Chief Olusegun Obasanjo, (Federal Republic of Nigeria, 2001, p.4) aptly observes that:

Youths are the foundation of a society. Their energy, inventiveness, character and orientation define the pace of development and security of a nation. Through their creative talents and labour power, a nation makes giant strides in economic development and socio-political attainments. In their dreams and hopes, a nation finds her motivation; on their energies, she builds her vitality and purpose and because of their dreams and aspirations, the future of a nation is assured.

In these few words, the former president was able to present succinctly, the essence of the role of youths in nation building. On the one hand, he outlined their potentials and the promises youths hold for their societies. On the other, he failed to emphasize that all these could only be possible in a society which allows and encourages the youth to develop their potential, find positive avenues to express it and be encouraged to develop such potential further. This begs the question about the attitude of the various government and leadership in Nigeria towards the youths since 1960 when the nation was granted independence. Such neglect of the other side of the youth spectrum makes it critical to review the circumstances surrounding the efforts that have been made to enable the youth develop and find expression for their inherent talents and abilities especially in a knowledge-driven market economy of this millennium.

At independence, the young Nigerian nation held so much promise for the youth. The reason for this is not far-fetched; those who had championed the nationalist movements and succeeded in wrestling political power from the colonial overlords had begun their agitations when they were youths. As such, it was widely accepted that their individual experiences as youths would largely influence their policy initiatives and directions, having personally appreciated the enormous contributions of youths to Nigeria's emancipation from colonial subjugation first-hand. Reference is made to Dr. Nnamdi Azikiwe (Zik of Africa), Chief Obafemi Awolowo, Sir Abubikir Tafawa Balewa, etc. Many Nigerians therefore concluded that the government, at the centre and within the regions, would initiate policies that would accommodate the aspirations of the youths. To an extent, this was the case as between 1960 and 1980. The central and the regional governments initiated programmes directed at youth development within their areas of influence. According to Global Network for Peace and Anti-Corruption Initiative (GNPAI) (2012), such policies "ranged from in-school educational programmes for physical and mental development to out of school programmes aimed at shaping the attitude and behaviour of youths as well as promoting team spirit, national unity and integration". Some regions, such as the Eastern region, embarked on agricultural development and the youths were constructively involved. By 1973, the National Youth Service Corps (NYSC) was established to further promote unity and integration through the youths as well as serve for the youths a means of acquiring practical work experiences before searching for more permanent employment, and for contributing to national integration and development. Furthermore, the military government at that time saw beyond the nation's immediate present and decided to prepare the youth for the future leadership of the country. This was done with a view to giving them the proper guidance and orientation relevant to the needs of the country. Then came the military rule.

According to Sen (2010), "the military would rule Nigeria for about 30 years and come to largely shape the socio-economic and politics of the country. Military rule would destroy democratic structures and processes and negate consensual or participatory development for a long period". Within this period therefore, Nigeria experienced several regional and national political upheavals, debilitating military coup d'états, assassinations and military rule; survived an internecine civil war (1967-1970), wasted the advantages and opportunities of an oil boom economy (1970-1990), suffered the tightening pangs of an Austerity Measure (under Shagari's 
administration) and a Structural Adjustment Programme (under Ibrahim Badamosi Babangida's administration), heaved impromptu sighs of relief with the various hic-cups of transitions to civil rule only to be plunged back into succeeding periods of prolonged, hegemonic military dictatorship that only succeeded in further eviscerating democratic ethos. The cumulative impact of these turbulent national travails and subsequent return to 'commandist militocracy' was that by 1990, youth development in Nigeria had suffered a surfeit of total neglect.

At this point, those strong norms and sanctions and institutions which backed the fixed modes of behaviour in the society became extensively weakened. Implementation mechanisms of existing policies became pathetically weak just as social, economic and political insecurity worsened the situation. According to the GNPAI (2012), "by the 1990s, youth development had become increasingly equated with sporting activities and competitions" to the detriment of the vast majority of youths who did not possess sporting skill or aptitudes but who also desired to develop the non-sporting but nevertheless, useful skills they possessed, and which were critical to national development. GNPAI (2012) further observes that "programmes for civil education and leadership training suffered severe setbacks. The issue of empowerment was hardly ever addressed". Attempts at youth development within this period therefore lacked the will, tenacity and sincerity of the leadership. Such lacklustre efforts towards the development of the youths variegated but inter-connected skills were proved ineffectual.

It should be noted that by this period, the Nigerian youth had become disenchanted with himself and his environment. The youths' desire for qualitative and functional education, challenging but fulfilling employment and general wellbeing became mortgaged as social and cultural values steepened in decline (Iheriohanma, 2009). The emerging negative realties of their environment weighing down on their mind, it didn't take much more for youths to develop and tenaciously hold the idea that Nigeria had become a jungle of which only the toughest, the meanest could hope to survive. This perceived hostile atmosphere in the country resulted in massive emigration of youths to Europe and Asia, increasing delinquency, restiveness, hard-drug merchandising and usage, violence and crime, poor social orientations and attitudes and an overwhelmingly furious urge to 'get rich' by all means. This saw the era of insurgent fraudsters $(419 s)$, ritual killers and emergent praise singers (Oti nkpu) to the gallery. Added to these was the sharp upsurge in pre-marital sex and teenage pregnancy which increased alongside school drop-out rates just as school enrolment decreased. Sadly but truthfully, Sexually Transmitted Diseases (STDs) and Sexually Transmitted Infections (STIs) became status symbols among the youth and those youth who survived one or more of such diseases usually basked in the misguided belief of their invincibility as manifest in their narrative of their exploits and survival to their peers. At this point, it was blatantly evident that the Nigerian nation has failed and has left its youth behind.

With the return to civil rule in 1999 came flickers of anticipation among many Nigerian youths. The general expectation then was that the limits imposed by the long period of 'uncivil' military rule would be coming to an end. It was also believed that upcoming youth development programmes and policies would be characterized by less rhetoric and more concrete action. More so, this feeling was heightened when Nigeria joined other nations of the globe in giving assent to the United Nations Millennium Declaration in the year 2000 after which she consequently adopted the Millennium Development Goals (MDGs). The Nigerian youth was caught up in the euphoric belief that poverty, mass illiteracy, inadequate development of skills, failing socio-economic and infrastructural facilities, housing, water, roads, healthcare services, etc. were about to become a part of our national history. What then are these Millennium Development Goals (MDGs)?

\section{The Millennium Development Goals (MDGs)}

Igbuzor (2006) opines that:

In order to address the problem of poverty and promote sustainable development, the United Nations Millennium Declaration was adopted in September, 2000 by the largest ever gathering of Heads of States, committing countries, both rich and poor, to do all they can to eradicate poverty, promote human dignity and equality, and achieve peace, democracy and environmental stability.

Following this famous declaration, the Millennium Development Goals (MDGs) became the yardstick with which human progress across nations would subsequently be measured. These goals were made time-bound and 2015 was set as the ultimate date. Hence, it was expected that by the year 2015, nations that are signatories, including Nigeria, would have appreciably attained the following eight-point goals which make up the MDGs viz:

1) Eradication of poverty and hunger.

2) Achievement of universal primary education.

3) Promotion of gender equality and empowerment of women. 
4) Reduction of child mortality.

5) Improvement of maternal health.

6) Combating HIV/AIDS, malaria and other diseases.

7) Ensure environmental sustainability.

8) Development of global partnership for development.

Laying more emphasis on the MDGs, the United Nations Development Programme (UNDP) in its 2006 MDGs report stated that:

The MDGs focus on three major areas of human development. These are: bolstering human capital, improving infrastructure, and increasing social, economic and political rights with the majority of the focus going towards increasing basic standards of living.

It further added that "the goals chosen were intended to increase an individual's human capabilities and advance the means to a productive life".

Basically, the above goals translate to the fact that (i) poverty must be reduced such that every Nigerian can have access to the basic necessities required for living, (ii) all Nigerian children must be afforded the opportunity to complete a full course of primary schooling irrespective of financial constraints, (iii) all forms of gender discrimination must be abolished and the feminine gender should be provided such opportunities as to compete favourably with the masculine gender, (iv) the high death rate among children must be reduced, (v) provision of better health services to expectant and nursing mothers must be achieved.

Being human-centric, it would not be wrong to state that the over-riding purpose in formulating and adopting the Millennium Development Goals (MDGs) is to ensure that every human being is provided: an environment and abilities in which he can thrive; tools with which to shape his destiny; good health with which to pursue and achieve his aspirations and concretize dreams, and by extension, the peace of mind (an outcome of the above) with which he needs to be a constructive contributor to his immediate and wider environment. This in other words could be equated with improved quality of life for all people, especially the youths.

Moreover, youths as well as being part of the intended beneficiaries of the Millennium Development Goals (MDGs) are also to be part of its driving force. This fact was emphasized by His Excellency, Thaksin Shinawatra (Prime Minister of Thailand) when he observed that "young leaders represent our hope for the future, and have the greatest potential to push for realization of the Millennium Development Goals (MDGs)". Along the same line, Ubi $(2007$, p.2) avers that "at the very foundation of this important role of the youth is the challenge of their participation in the quest towards nation building".

\section{Millennium Development Goals and Youth Development in Nigeria}

The year, 2012 marks the twelfth year since Nigeria, along with several other nations of the world, adopted the Millennium Development Goals (MDGs) as a mandate by which the leadership would move the country up the development ladder. According to Igbuzor (2006):

There is a general consensus that development will lead to good change manifested in increased capacity of people to have control over material assets, intellectual resources and ideology; and obtain physical necessities of life (food, clothing \& shelter), employment, equality, participation in government, political and economic independence, adequate education, gender equality, sustainable development and peace.

What this means is that development is the driving force of change and this change underlines the objective of the Millennium Development Goals (MDGs).

According to the Nigerian MDGs Report (2010, p.4), "Nigeria is making real progress. Recently implemented policies are accelerating the achievement of the Millennium Development Goals (MDGs). These gains are based on sustained economic growth, improvements in planning and policy, and growing government investment in the social sector". Disagreeing with the above assertion, Anozie (2010) laments that "Nigeria is woefully behind in achieving the United Nations Millennium Development Goals .... Nigeria still remains off track to meeting the goals by $2015 \ldots .$. Nigeria is off track to eradicating extreme poverty, reducing child mortality, and improving maternal health". This is primarily as a result of the dysfunctional socio-economic and political atmosphere of the Nigeria environment. The impact remains weak institutional framework and poor policy implementation which cumulatively and continuously, imposes a burden of neglect on the youth. The weak institutional framework and the attendant structural strain inflicted challenges on the youth to acquire necessary skills and knowledge needed for survival in a knowledge-driven and competitive economy. 
With regards to policy implementation, Okoroafor and Anuforo $(2012$, p.67) assert that "effective policy implementation can be very instrumental for achieving the Millennium Development Goals (MDGs). They further argue that effective policy implementation should drive all other factors necessary for the realization of the Millennium Development Goals (MDGs) in Nigeria. The reality though remains that policy implementation initiatives in the country are largely rhetoric, tending to sell more newspapers and political candidates than they benefit the people for whom they are meant to benefit. Institutional frameworks that ought to ensure objectivity and accountability in implementation of policies are desperately weakened and continue to stifle implementation of the Millennium Development Goals (MDGs). Okoroafor and Anuforo (2012, p.70) went further to highlight the factors constituting impediments to effective implementation of the Millennium Development Goals (MDGs) to include: (i) corruption and criminality (ii) bad leadership and poor governance (iii) ethnicity and nepotism (iv) slow [inefficient] public service structure and (v) lack of continuity of policies. These factors persist yet and continue to weaken efforts at achieving the Millennium Development Goals (MDGs).

The Nigerian National Youth Policy and Strategic Plan of Action in its 2001 report observe thus:

Nigerian youths have suffered more neglect than encouragement, and purposeful involvement by the government. Contemporarily, they suffer from different kinds of socio-economic deprivations and afflictions, which have been intensified with prolonged military rule and acute economic crisis. Thus, Government's efforts, when made, have generally tended to be too little too late. The institutional framework for and plan implementation mechanisms of public policy have been very weak, inefficient and ineffective, such that they hardly ever facilitated the actualization of desired policy goals.

The intensity of the impediments to policy implementation emasculates the ability of the government to derive inherent benefits of the Millennium Development Goals (MDGs) required to create the needed environment and spur for critical youth development. Qualitative education in terms of critical knowledge, skills and orientation, poverty eradication, skills development and employment, socio-economic integration, health and access to soft loans remain beyond the reach of majority of the youths in Nigeria. Okafor (2011, p.359) adds that "the problem of chronic youth unemployment is very evident in Nigeria. Every year thousands of graduates are turned out for whom there are no jobs. Nigerian streets are littered with youth hawkers who ordinarily would have found gainful employment in some enterprises. The self employed are in quandary as scant infrastructure makes it impossible for them to ply their trade". Roads, power supply, security are decadent and deficient; and capital is difficult to raise because of the huge collateral attached.

In real economic terms, the living condition to which the Nigerian youth is subjected appears to grow worse with each passing day. The dysfunctional Nigerian society, where its teeming youths, especially the educated ones, remain unemployed, cannot be said to have achieved much in terms of youth development. Adejumobi (2011) remarks that:

Graduate unemployment in Nigeria is over $50 \%$, poverty rate of less than $\$ 2$ per day is over $70 \%$, basic infrastructures have completely collapsed [in terms of] electricity, water, good roads, etc. There is general insecurity, and an oil exporting country imports refined petroleum for its local use so that oil buccaneers can live off the sweet of the people. Nigeria runs perhaps the most expensive civilian government in the world - the National Assembly consumes significant percentage of the national budget; some past leaders, who were virtually broke before luck smiled on them with state power now own private jets that they travel in; and some others who have little or no knowledge about the oil industry now own oil wells, which they sell for raw cash. The picture is that of a jungle.

Added to the above, some well-known self-acclaimed religious leaders now own private jets and move about in the guards of state security, a situation that has infused doubts in the minds of their followers about their spiritual leadership. As members of a society, the conditions of the youths are largely dependent on those of the society. Therefore, being "physically robust, morally idealistic, and willing and able to invest substantial amounts of their time and energy to the pursuit of causes in which they believe" (Mabogunje, 1988), it was not surprising therefore at the ease and vigour with which they imbibed and took to new heights, those pervasive narrow and shallow socio-economic objectives that had set over the Nigerian nation by the turn of the $21^{\text {st }}$ century. Undisciplined, morally inept, poorly educated and having so much unproductive time, the Nigerian youth, for want of survival, became a fertile candidate for armed robbery, militancy and insurgency, kidnapping, political thuggery, prostitution, drunkenness, trafficking and use of hard drugs and debilitating health problems. Since the challenges are on a daily basis for the youths, they developed an over-arching urge to 'make it' irrespective of the means but with a keen eye on a personally set time frame. Their innovative skills and creativity turned to be negative instead of development oriented. 


\section{Concluding Remarks}

Despite the twelve years that have elapsed since Nigeria adopted the Millennium Development Goals (MDGs), Nigeria still grapples with extreme problems associated with poverty and hunger, Universal Primary Education, women empowerment, high child mortality rates, health problems, etc. The Millennium Development Goals (MDGs) seem poised to toe the path of previous development programmes that Nigeria in her chequered history has adopted and abandoned.

Government as a matter of fact has tried to address the challenges of the youths through various youth development programmes. In 2011, the Federal Government of Nigeria adopted a comprehensive Youth Employment Policy. This policy entailed programmes whose focal objective was job creation and transformation of the youth into entrepreneurs and employers. There was also the introduction of Youth Development Centres and Skill Acquisition Centres which led to the establishment of National Entrepreneurship Centres in almost all tertiary institutions in Nigeria. The National Directorate of Employment (NDE) and National Poverty Eradication Programme (NAPEP) were consequently harmonized and enhanced. In addition, technical and vocational skills were emphasized through the introduction of the National Secondary Education Curriculum. These and many others are laudable programmes but the impact has remained infinitesimal considering the enormous effects of globalization and the attendant unemployment rate, especially in the Third World countries. The reason is primarily because the institutional frameworks that would have ensured proper implementation were weak and at best fragile thereby enabling politicians and other executives to blatantly hijack and distort the programmes and circumstances for their own spurious gains.

Government policies therefore have not been able to properly address the magnitude of challenges that daily accost the youths. According to the Commonwealth Youth Representative in Nigeria, Ewa Asala (News Metro, 2012), "the fact is that being a young person in Nigeria is no longer a pleasurable experience. The burden of survival is out-weighing the ability to carry the burden". Political commitment remains weak and as such, it is becoming more difficult to formulate and implement concrete strategies for youth development deriving from the Millennium Development Goals (MDGs). This makes poverty to continue to affect young people in striking and personal manner. It also cuts across all their needs. Gender equality remains beyond the horizon as young women still lack equal opportunities in education and employment with their men folk. Weak institutional capacity also perverts the implementation of the Millennium Development Goals (MDGs) such that it is difficult for the envisaged gains to reach those who deserve it the most, the youths.

\section{Recommendations}

Nigeria is a country imbued with great development potentials. Much of these critical potentials lie in the abundant human resources, especially the youths. To tap these potentials requires the ability to review the institutional frameworks in the Nigerian sphere. All hope is not lost as a look beyond the immediate socio-economic and political constraints that stunt youth development will reveal a possible brighter future. The government can still get back on track, reverse the current trend and become truly committed to achieving the objectives of the Millennium Development Goals (MDGs). As most of the policy initiatives of the government towards this direction (achieving the MDGs) are continually withered by poor implementation, the government should revitalise or reformulate the institutional frameworks that will obviate these challenges. This will not only increase the chances of achieving the Millennium Development Goals (MDGs) but also facilitate concrete socio-economic and political change in which the Nigerian youths have better development options.

The Ministry of Youth Development should begin to live up to the youths' expectations and make meaningful impact by taking advantage of the large population of youths in Nigeria. The education system which provides students with more theoretical knowledge should be overhauled to provide them critical practical skills as is obtained in other climes. Problems associated with inadequate skills which make the Nigerian youths inadequate, inefficient, unmotivated and uninspired should be changed by reforming all the skills acquisition centres in the country. Efforts should be made to inculcate in the youths critical skills and knowledge that give them the competitive edge required in this competitive and knowledge-driven market economy. When this is done, the misery and frustration which the youths are faced with presently will be reduced within a short period and the tendency to resort to vice and other violent crimes will decrease appreciably. This paper is "convinced that Africa's [Nigeria's] greatest resource is its youthful population and that through their active and full participation; Africans [Nigerian's] can surmount the difficulties that lie ahead" (AYC, 2006, p.1).

Efforts should be made in the Third World countries of Africa, Nigeria especially, to strengthen the institutional structures of governance and administration to make them stronger than personalities to face the realities of the flogging effects of globalization and information and knowledge age. Globalization has come to stay and it is 
even waxing stronger to the extent that its toll on the developing countries' economy is not only becoming treacherous but its effect on the erosion of traditional and informal sector economy has now overwhelmingly and stealthily inflicted more on the excruciating pains on the youths in the areas of unemployment. The youths are worse off the situation and governments in these countries should brace up the realities now before the gun powder is lit up.

The present Federal Government's Transformation Agenda of President Goodluck Jonathan would only be meaningful to the citizenry if its focus was primarily on job creation and youth empowerment. Youth development should be given priority attention in the ongoing constitutional review efforts in Nigeria. This would drastically reduce many of the challenges facing youths and stimulate pragmatic development of their skills, knowledge, etc. Youth development and empowerment is hereby referred to as a foundation stronghold to facilitating the achievement of Nigeria's quest of being among the strongest twenty economies by the year 2020 .

\section{References}

Adejumobi, S. (2011, February 21). Lessons: Tunisia, Egypt and Sudan. The Guardian.

African Forum and Network on Debt and Development (AFRODAD). (2005). The Politics of the MDGs and Nigeria: A Critical Appraisal of the Global Partnership for Development (Goal 8). Retrieved from http://www.afrodad.org on 21/03/2012

African Youth Charter (AYC). (2006, July 2). Adopted by The Seventh Ordinary Session of African Union Assembly held in Banjul.

Anozie, S. (2010). Nigeria and the Millennium Development Goals: Where We Are and How You Can Make a Difference. Retrieved from http://www.shadenoncomformist.blogspot.com on 06/09/2011

Bamidele, T. B., Joseph, A. I., \& Oresajo, A. L. (2013). 'Corruption in Nigeria: An Impediment to Achieving the Millennium Development Goals'. Journal of Economics and Sustainable Development, 4(1), 10-16.

Chine, B. C. (2003). Value Orientation and National Commitment: Challenges to Nigerian Youths. In O. O. Obiajulu (Ed.), Readings in Humanities Enugu: John Jacobs Classic Publishers Limited.

Chukuezi, C. O. (2009). 'Poverty and Youth Restiveness in Nigeria: Implications for National Development'. Ozean Journal of Social Sciences, 2(2), 97-103.

Chukwuemeka, E., Okoye, J. C., Muo, M. C., \& Anazodo, R. (2012). 'Youths and Career Development in Nigeria: Problems and Prospects'. Arabian Journal of Business and Management Review (OMAN Chapter), 1(9), 77-88.

Ewe Asala cited in J. Oba. (2011). 'Nigeria Youth in 2011'. News Metro, 03/01/2012.

Federal Republic of Nigeria. (2001). National Youth Policy and Strategic Plan of Action. Retrieved February 5, 2012, from http://www.thepresidency.gov.za/docs/policy/

Global Network for Peace and Anti-Corruption Initiative (GNPAI). (2012). Nigeria of Our Dream: The Role of the Youth. Retrieved October 3, 2012, from http://www.gnpai.com/publications/Nigeria

Igbuzor, O. (2006, March 9). Review of Nigerian Millennium Development Goals 2005 Report. Paper presented at the Millennium Development Goals Planning Meeting held in Abuja, Nigeria.

Iheriohanma, E. B. J. (1999). Sociology: A Practical Understanding of Social Reality: Second Edition. Owerri: Tropical Publications.

Iheriohanma, E. B. J. (2009). 'Socio-Cultural Pressures and the Challenges of Survival and Crime Committal in Nigeria'. Journal of Social Science, 21(3), 167-175. Retrieved June 26, 2013, from http://www.krepublishers.com

Mabogunje, A. L. (1998). Challenges of a U-Turn Generation: Youth and National Conference in Youth Development in Kaduna State. Nigeria.

Nigerian Millennium Development Goals Report. (2010). Retrieved March 21, 2012, from http://www.mdgs.gov.ng

Okafor, E. E. (2011). Youth Development and Implications for Stability of Democracy in Nigeria. Journal of Sustainable Development in Africa, 13(1), 358-373.

Okoroafor, E. C., \& Anuforo, E. E. (2012). 'The Millennium Development Goals (MDGs) and the Problem of Policy Implementation in Nigeria'. International Journal of Development and Management Review (INJODEMAR), 7(1), 63-73. 
Olasunkanmi, A. (2009, December 17). State of the Nigerian Youth Sector. Being the text of the 2009 Ministerial Press Briefing Addressed By The Honourable Minister Of Youth Development, at The Nicon Luxury Hotel, Abuja. Retrieved November 15, 2012, from http://economicconfidential.net/new/focus

Olujide, M. G. (2008). 'Attitude of Nigerian Youths Towards Rural Development Projects in Lagos State Nigeria'. Journal of Social Science, 17(2), 163-167.

Onuekwusi, G. C., \& Effiong, E. O. (2002). 'Youth Empowerment in Rural Areas through Participation in Rabbit Production: A Case Study of Akwa Ibom State, Nigeria'. Nigerian Journal of Rural Sociology, 4(1), 95-99.

Otive, I. (2006, March 6). Review of Nigerian Millenium Development Goals 2005 Report. Paper Presented at the MDG/GCA Nigeria Planning Meeting Held at Abuja, Nigeria.

Ploch, L. (2013). Nigeria: Current Issues and U.S. Policy. Being text of Congressional Research Service (CRS) report for the United States Congress. Retrieved June 12, 2013, from http://www.crs.gov

Sen, Y. (2010). Challenges and Prospects of Nigeria's Development at 50. Paper presented at Golden Jubilee Symposium Paper at Carleton University, Ottawa, Canada, 30th September 2010. Retrieved November 5, 2012, from http://www.simplynigeria.com/content

Thaksin Shinawatra 10 Statement to the Pan-Asian Youth Leadership Summit. (2004, September). UNESCO's Contribution: Empowering Youth through National Policies. Retrieved September 6, 2011, from http://www.unesdoc.unesco.org

Ubi, E. N. (2007, October 16-19). African Youths Charter: Prospects for the Development of the Youth. Paper presented at the Workshop on the Appropriation, Dissemination and Implementation of Regional instruments and Endogenous Democratic Governance and Conflict Preventions Mechanisms in West Africa held in Dakar, Senegal.

United Nations. (2006). The Millennium Development Goals Report 2006-United Nations Development Programme. Retrieved January 23, 2012, from http://www.undp.org/publications/MDGRreport2006

Yusif, M. M. (2008). Role of Youths on the Forthcoming Local Government Polls in Jigawa State. Paper presented at YDC forum in Dutse, Jigawa State on Tuesday, 15 April, 2008. Retrieved July 21, 2012, from http://www.mmyusuf.blogspot.com/2008/04/role-of-youths-on-forthcoming-local.html

\section{Copyrights}

Copyright for this article is retained by the author(s), with first publication rights granted to the journal.

This is an open-access article distributed under the terms and conditions of the Creative Commons Attribution license (http://creativecommons.org/licenses/by/3.0/). 